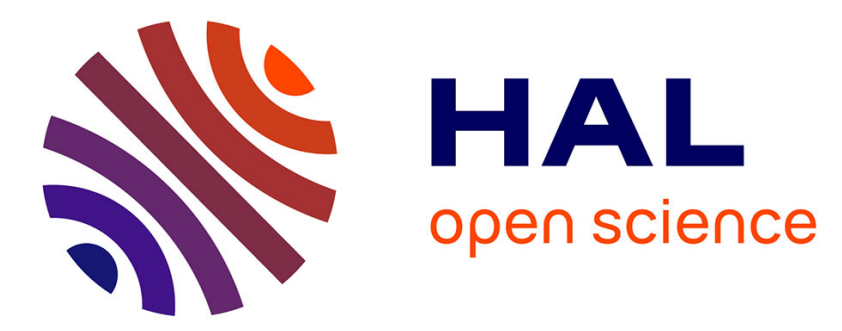

\title{
Numerical study of Trombe wall as a passive ventilation system: The case of Moroccan climate
}

Youssef Hamidi, Abdellah Bah, Mustapha Malha, Bouchra El Gharbi, Hajar Hafs

\section{- To cite this version:}

Youssef Hamidi, Abdellah Bah, Mustapha Malha, Bouchra El Gharbi, Hajar Hafs. Numerical study of Trombe wall as a passive ventilation system: The case of Moroccan climate. 7th International Renewable and Sustainable Energy Conference, IRSEC 2019, 2019, Agadir, Morocco. 2019. hal02878261

\section{HAL Id: hal-02878261 \\ https://hal.science/hal-02878261}

Submitted on 29 Jun 2020

HAL is a multi-disciplinary open access archive for the deposit and dissemination of scientific research documents, whether they are published or not. The documents may come from teaching and research institutions in France or abroad, or from public or private research centers.
L'archive ouverte pluridisciplinaire HAL, est destinée au dépôt et à la diffusion de documents scientifiques de niveau recherche, publiés ou non, émanant des établissements d'enseignement et de recherche français ou étrangers, des laboratoires publics ou privés. 
Numerical study of Trombe wall as a passive ventilation system: The case of Moroccan climate

Youssef HAMIDI, Bouchra EI GHARBI, Hajar HAFS, Mustapha MALHA, Abdellah BAH Centre de Recherche en Energie, Equipe de Recherche en Thermique et Energie (ERTE) ENSET-Mohammed V University Rabat, Morocco Roosevelt University

\section{Abstract}

Nowadays, as building's energy consumption has become of outstanding ing artance, passive solar design strategies such as Tromb world. In this context, the present work is intended to contribute to better understanding of the feasibility of using the Trombe wall as an effective natural ventilation technology in order to achieve potentia energy savings as well as acceptable thermal comfort conditions. To that aim, a mathematical model describing the thermal performance of the studied wall system was used, and then by means of comso Multiphysics software, a parametric study of a single room with four different wall configurations that differ only in the inlet and outlet a vent position was carried out under six Moroccan climate zones durin both winter and summer seasons. Temperature and velocily fields in simultion results, some usefll conclusions wer derived.

\section{Materials \& Methods}

\section{Meteorological data}

In order to obtain a wide range of climate conditions, the study was carried out for six Moroccan Climates: Agadir (Zone I), Tangier (Zone II), Fez (Zone III), Irane (Zone IV), Mar rakech (Zone V) and Er-rachidi (Zone $V$ ). Meteorological data, ambient air temperatures(Fig.1,2) and global solar radiation(Fig.3,4) and 2 d) periods have been anose 1 relevant winter and summertime weather conditions.

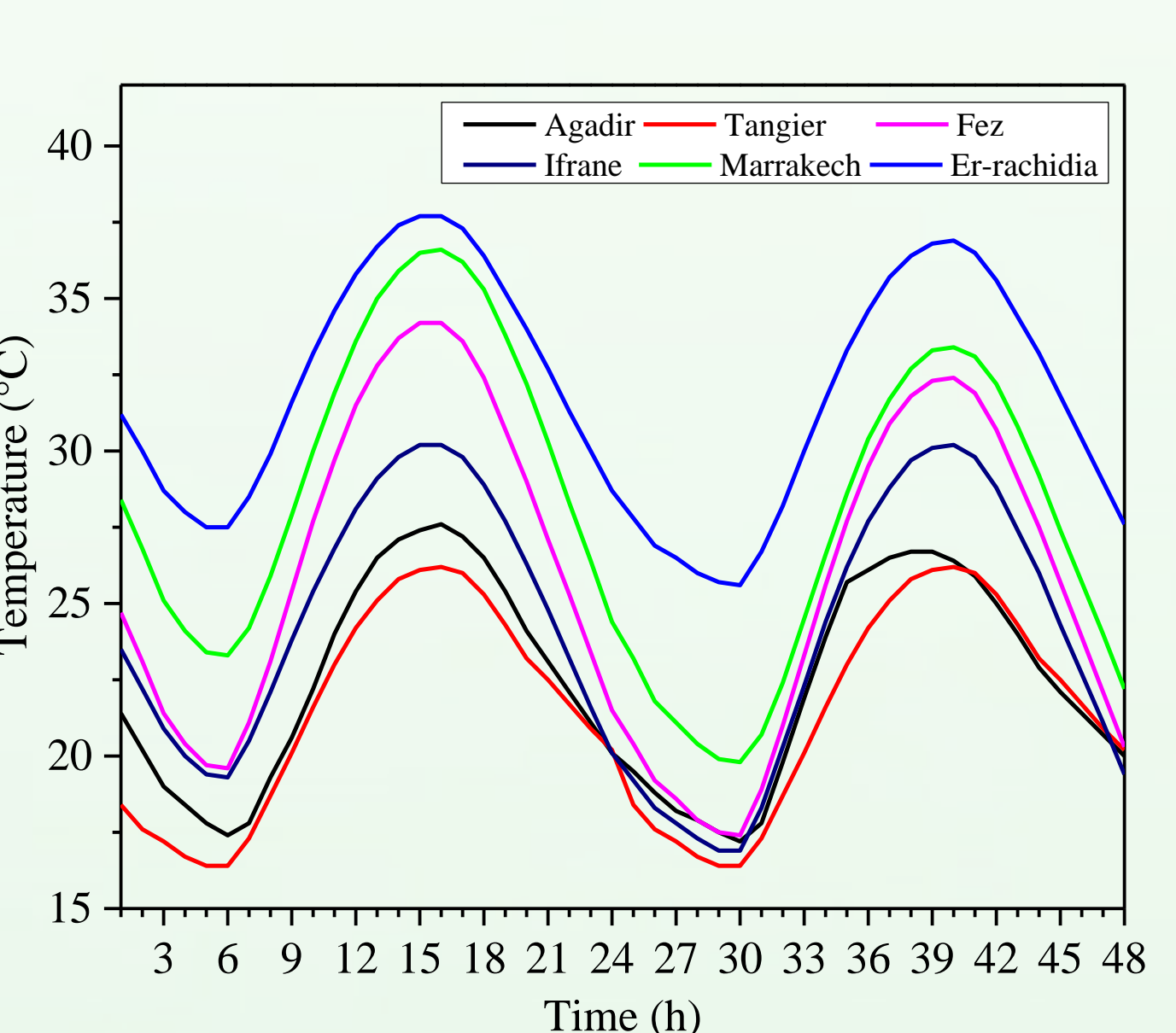

g. 1.Summer aimerbient temperature

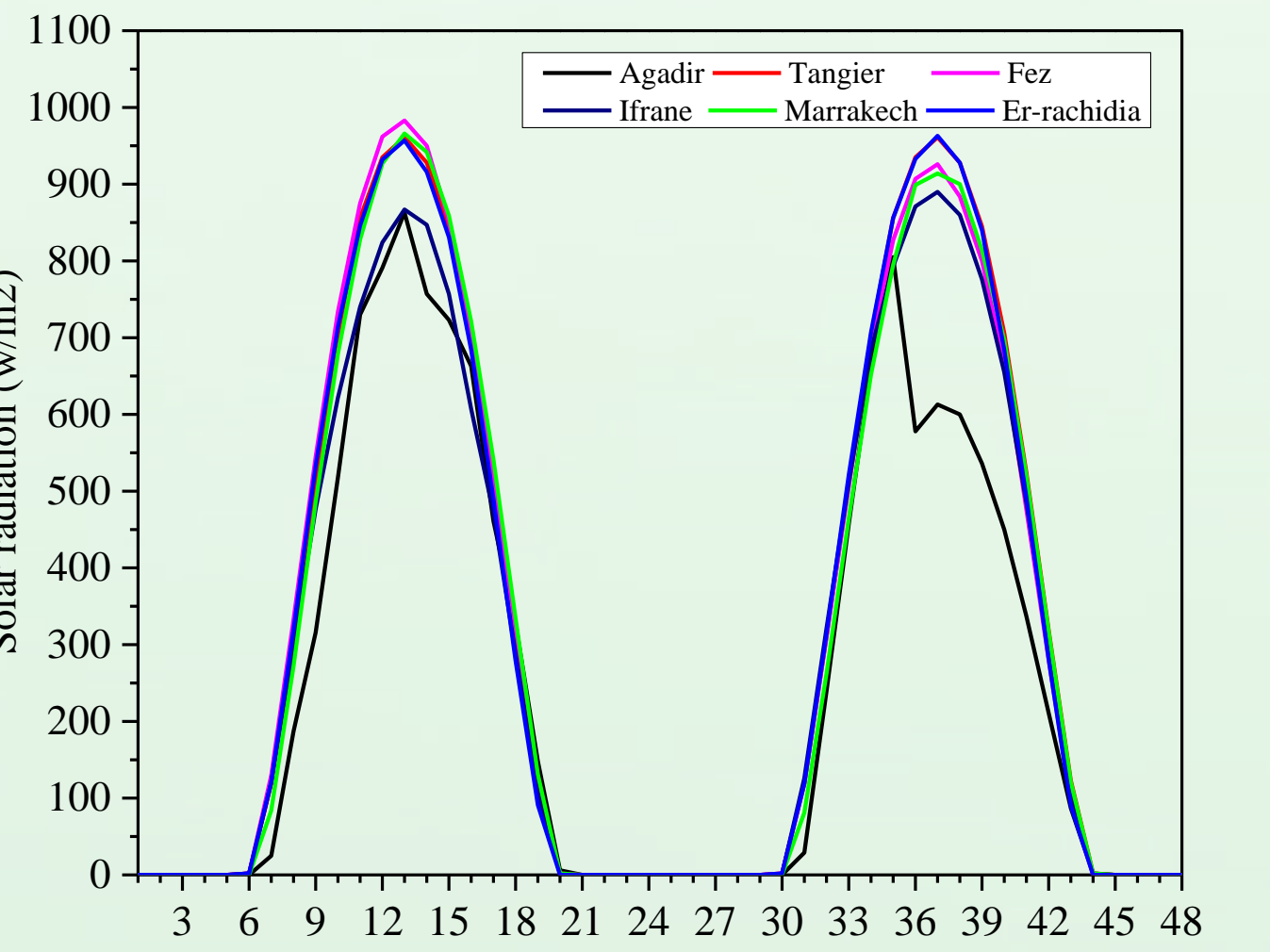

Fig. 3.Summer solar radiation

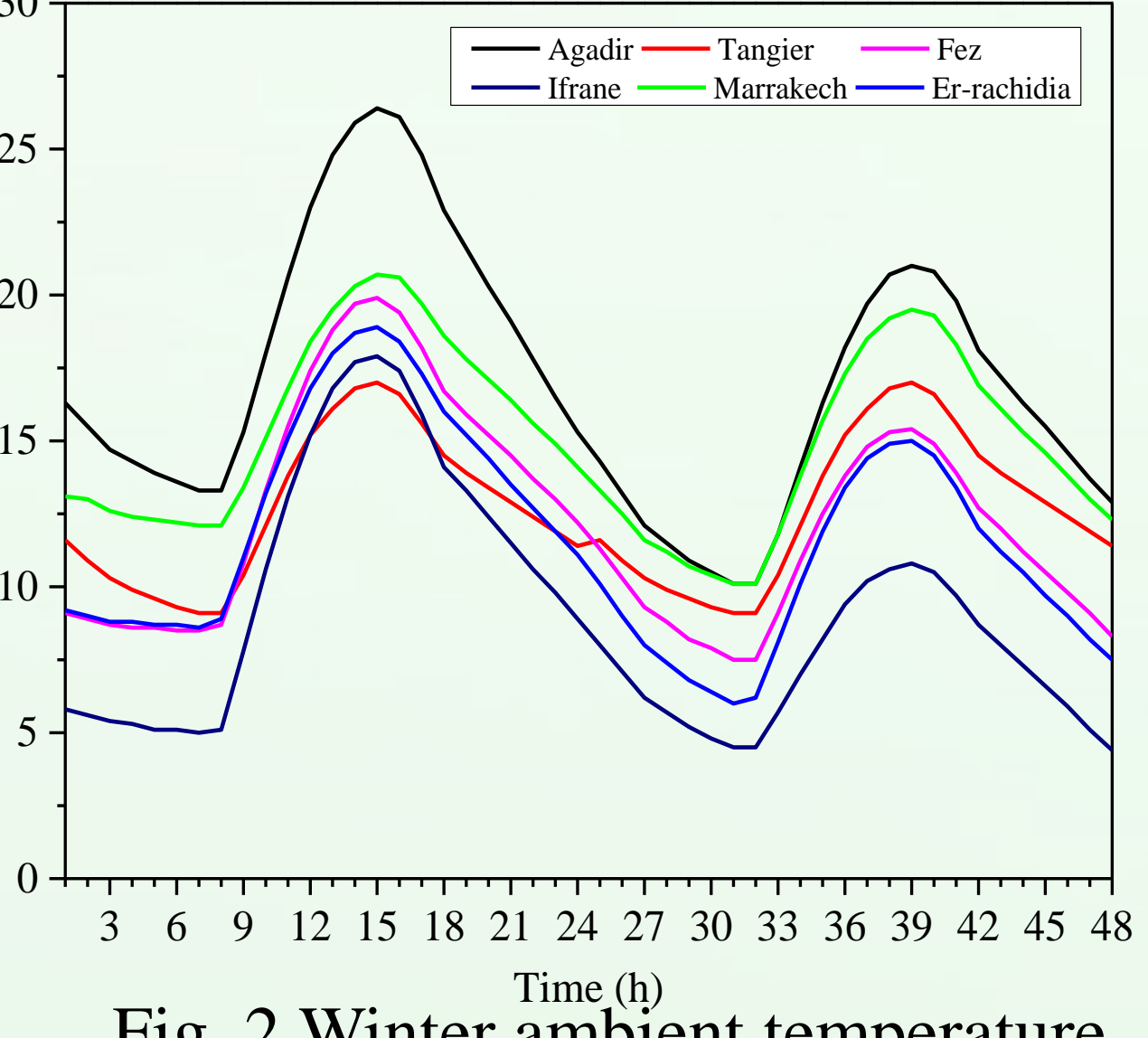

Fig. 2. Winter rambient temperature

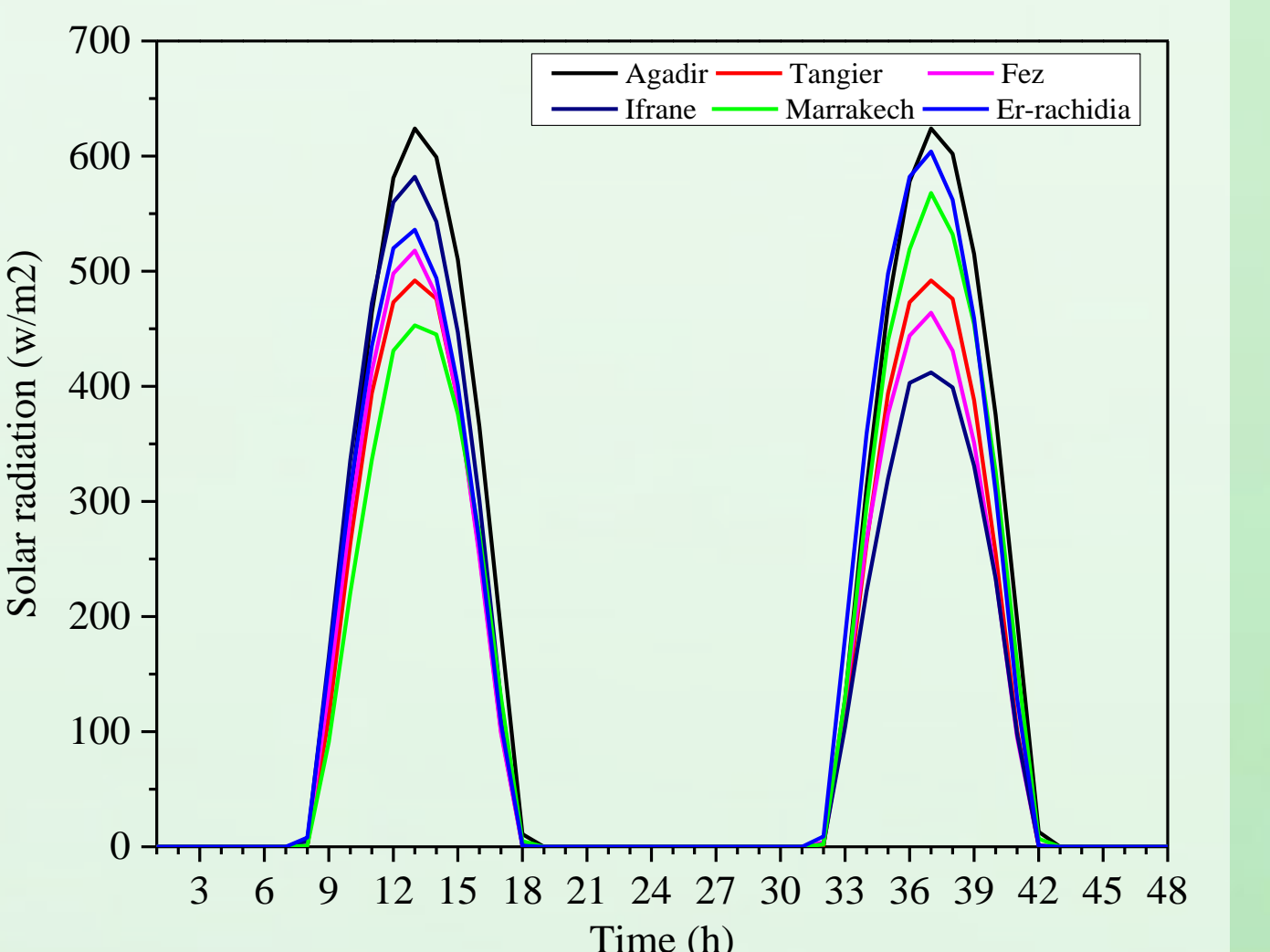

\section{Materials \& Methods cont.}

\section{Cell description}

For optimum control of the study, as shown in Fig.5-a, a virtual . Trombe wall was developed. This wall consists from the inner to the 0.05 ming 0.005 m the glass cover. As for the other walls, the roof, and the

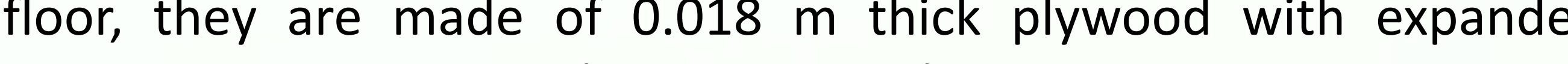
polystyrene insulation $(0.02 \mathrm{~m}$ thick) placed between the two

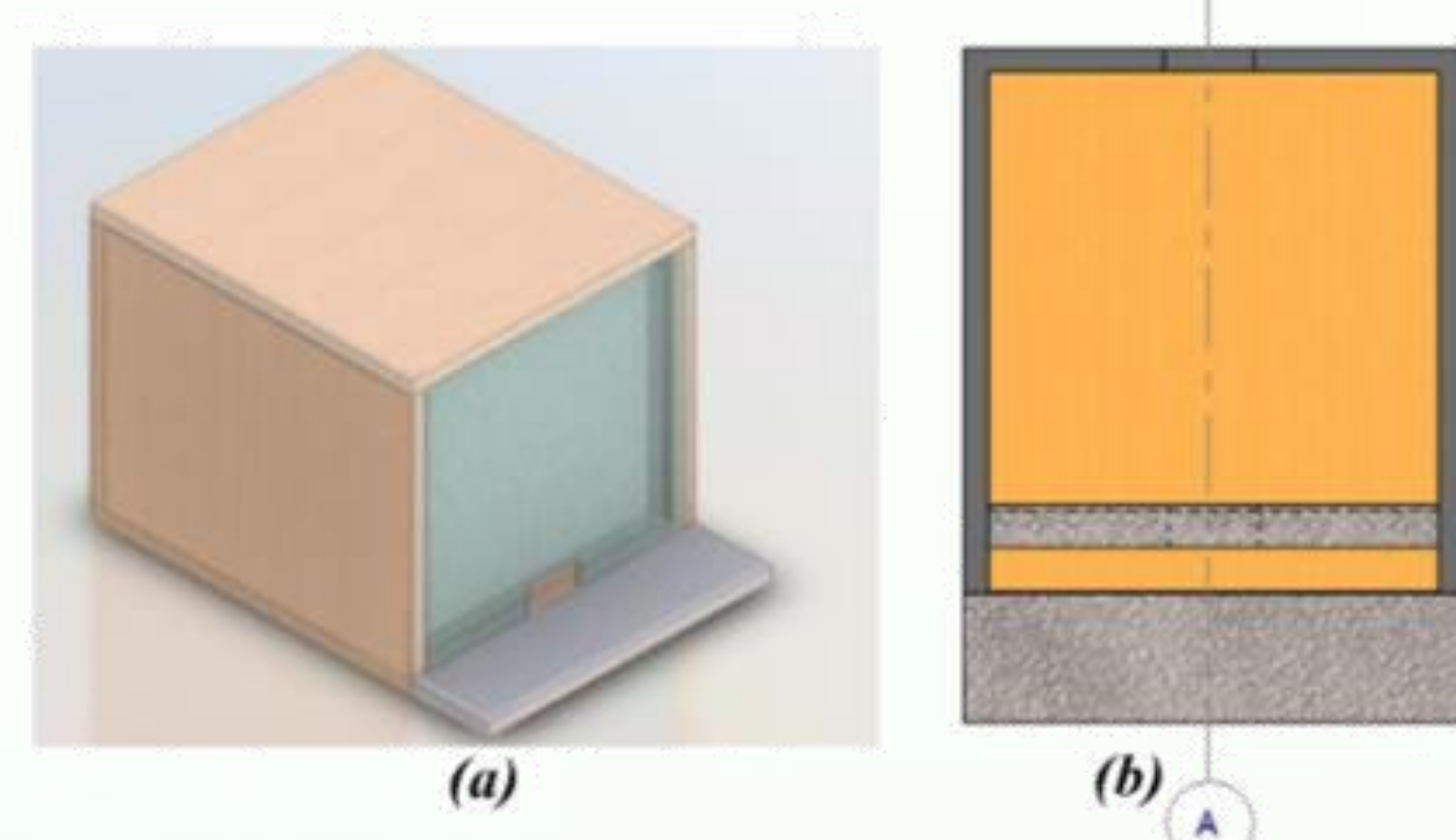

Fig. 5.Description of the studied cell: (a) 3D view, (b) floor plan A cross sectional view A-A (Fig.5-b) of the configurations design details is illustrated in Fig.6.

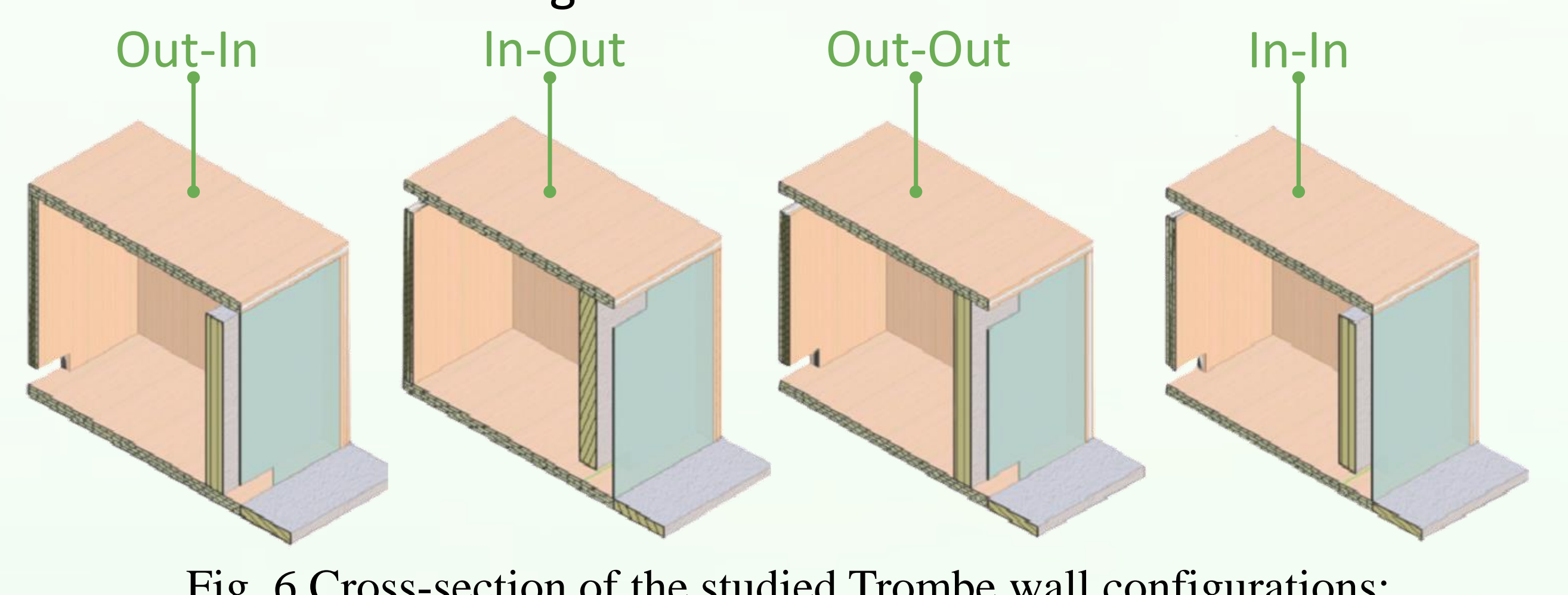

CFD model

COMSOL Multiphysics model was used in which heat transfer and fluid flow physics were coupled through the Nonisotherma Fow Multiphysics feature. The Fluid Flow module is based on the Navier-Stokes equations govenng conservation of mass, momentum, and energy, which may be written as follows:

$$
\begin{gathered}
\frac{\partial \rho}{\partial t}+\nabla \cdot(\rho u)=0, \\
\rho \frac{\partial u}{\partial t}+\rho(u \cdot \nabla) u=\nabla \cdot\left[-p I+\mu\left(\nabla u+(\nabla u)^{T}\right)-\frac{2}{3} \mu(\nabla \cdot u) I\right]+\left(\rho-\rho_{r f}\right) g,
\end{gathered}
$$

As for heat transfer, the governing equation is given by:

$$
\rho C_{p} \frac{\partial T}{\partial t}+\rho C_{p} u . \nabla T+\nabla . q=Q,
$$

$$
q=-k \nabla T,
$$

For heat transport urbulence chosen, in which Prandtl number is given by:

$$
\mathrm{P}_{\mathrm{P}_{T}}=\left(\frac{1}{2 \mathrm{P}_{T_{T \infty}}}+\frac{0.3}{\sqrt{\mathrm{P}_{\mathrm{T}_{\infty}}}} \frac{C_{P} \mu_{T}}{k}-\left(0.3 \frac{C_{P} \mu_{T}}{k}\right)^{2}\left(1-e^{-k / 0.3 C_{P} \mu_{r} \sqrt{\mathrm{P}_{T_{s}}}}\right)\right)^{-1}, \quad \text { (5) }
$$

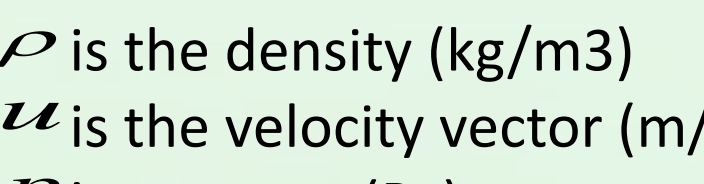

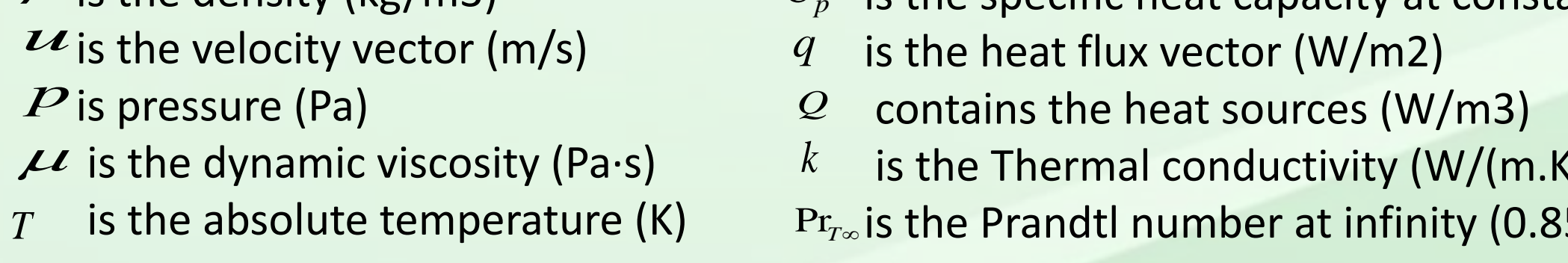

\section{Results \& Discussion} Air temperature and velocity distribution in the upper air ven for In-In and Out-In configurations) and the lower opening (for inOut configuration) during both winter and summer seasons are llustrated for each location in Fig. 7, 8, 9, and 10
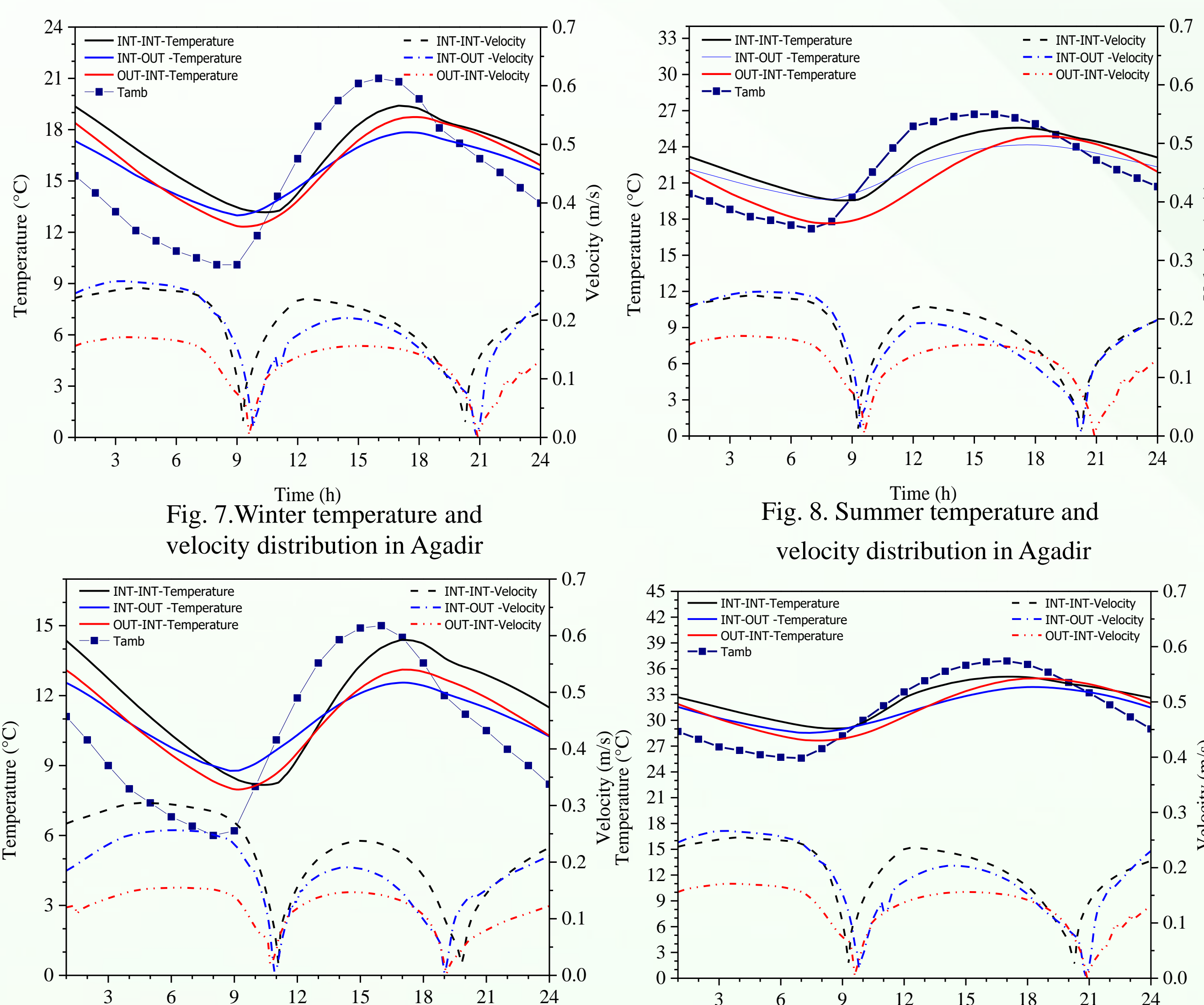

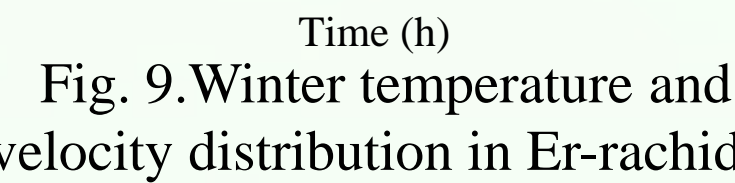

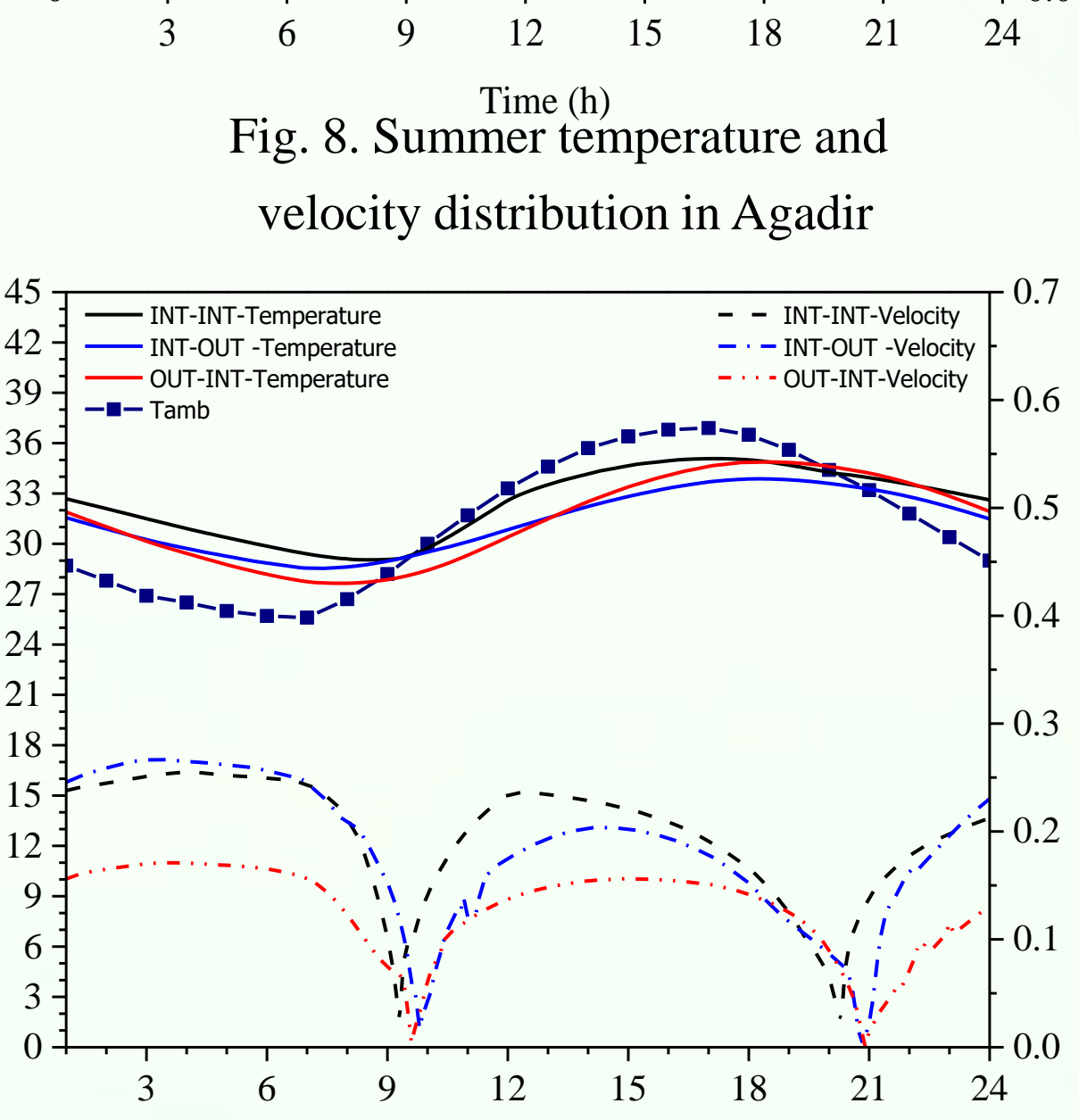

Fig. 10. Summer (ti)
velococity disture and
vistibution in Er-rachid

As can be seen in Fig.7 (Agadir case), During winter, the three studied configurations exhibited temperatures that exceeded the mbient in the nighttime, this temperature difference caused a free 0.27 and $0.17 \mathrm{~m} / \mathrm{s}$ respectively, for $\mathrm{In}-\mathrm{In}$, In-Out and Out-In configurations.

As regards summer season, Fig.10 clearly shows that in Er-rachidia case, daytime temperatures decreased below ambient, and the tack effect due to solar radiation caused a rise in air velocities which altaned $0.23,0.20$ and $0.15 \mathrm{~m} / \mathrm{s}$ respectively, for $\mathrm{h}-\mathrm{In}$, $\mathrm{h}$-O $\mathrm{O}$ t

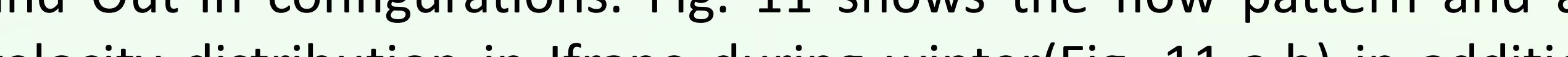
to Marrakech during a summer day at (Fig.11-c,d).

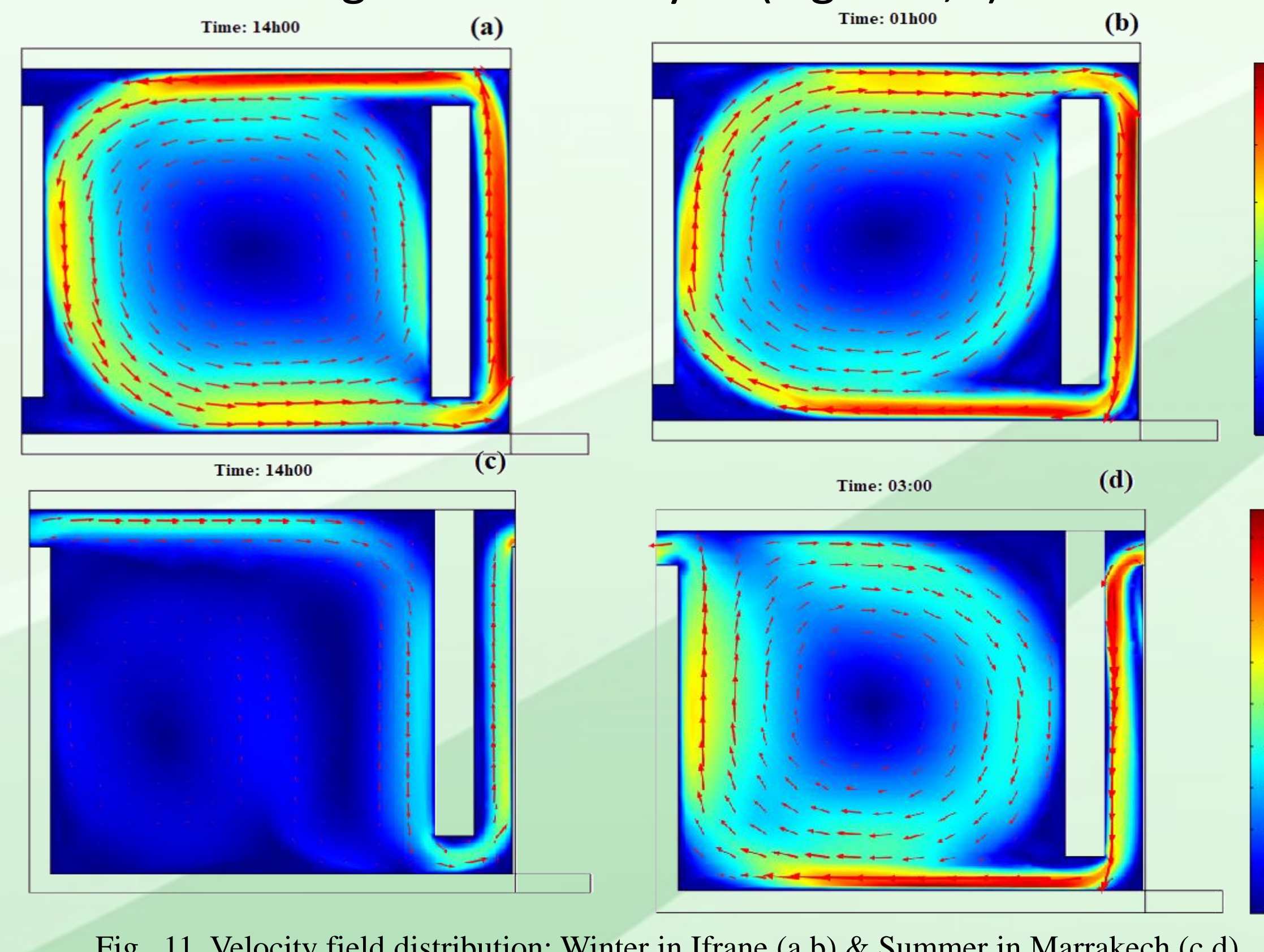

\section{Conclusion}

For the study, a numerical simulation was carried out for differen Trombe wall configurations in order to assess their efficiency as passive venth wilen techique under various Moroccan climate zones revealed that during the winter season, In-In configuration was found to be the most suitable solution; meanwhile in - Out configuration has proven most effective in the summer season.

Trombe wall may be considered as an effective natural ventilation technique; however, its integration into the building envelope requires more research on the parameters influencing its performance, such as air gap thickness and the glazing type.

\section{Future Work}

The Trombe wall could ensure better thermal comfort conditions when coupled with other passive technologies and prope

\section{References}

- AMEE National Agency for Energy Efficiency. http://www.amee.ma. - Arvind Chel, J.K. Nayak, Geetanjali Kaushik. Energy conservation in honey storage bulding using Trombe wall. Energy and Buildings 40 (2008) 1643-1650.

-Samar Jaber, Salman Ajib. Optimum design of Trombe wall system in mediterranean region. Solar Energy 85 (2011) 1891-1898. . Abbassi, N. Dimassi, L. Dehmani, Energetic study of a Trombe wal

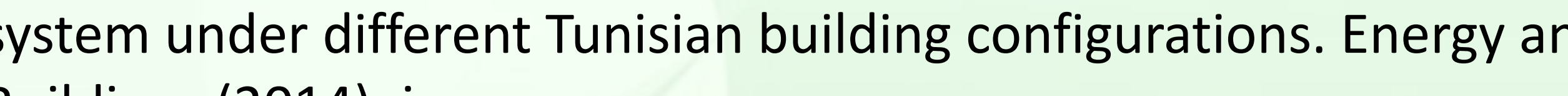
(

CFD Analyses for Passive House with Trombe Wall and Impact to Energy Demand. Energy and Buildings (2014)

\section{Contact Information}

Youssef HAMIDI youssef.hamidi@um5s.net.ma 0625134499

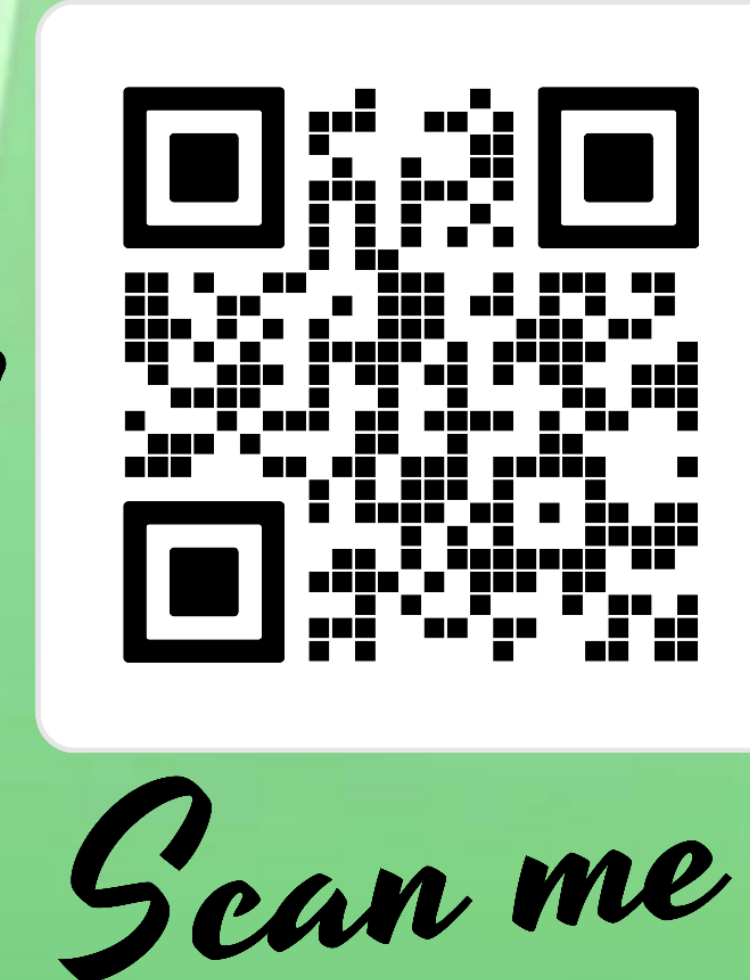

